SAS InstiTUTE INC. (2011): SAS SAS/STAT 9.3 Computer Software. Cary, N C, USA.

Schmidtling, R. C. (1994): Use of provenance tests to predict response to climate change: loblolly pine and Norway spruce. Tree Physiology 14(7-8-9): 805-817.

Soto-Correa, J. C., C. SÁenz-Romero, R. Lindig-CisNeros, N. M. SÁnchez-VARGaS and J. CRUZ-DE-León (2012): Genetic variation between Lupinus elegans Kunth provenances, altitudinal seed zoning and assisted migration. Agrociencia 46(6): 593-608.

ST. ClaIR, J. B. (2006): Genetic variation in fall cold hardiness in coastal Douglas-fir in western Oregon and Washington. Canadian Journal of Botany 84(7): 1110-1121.

Tchebakova, N. M., G. E. Rehfeldt and E. I. Parfenova (2006): Impacts of climate change on the distribution of Larix Spp. and Pinus sylvestris and their climatypes in Siberia. Mitig Adapt Strat Glob Change 11(4): 861-882.
Thomas, S. C. (2011): Genetic vs. phenotypic responses of trees to altitude. Tree Physiology 31(11): 1161-1163.

Van Zonneveld, M., A. Jarvis, W. DvoraK, G. Lema and C. LEIBING (2009): Climate change impact predictions on Pinus patula and Pinus tecunumanii populations in Mexico and Central America. Forest Ecology and Management 257(7): 1566-1576.

Viveros-Viveros, H., C. SÁenz-Romero, J. L. Upton and J. V. HERNÁNDEZ (2005): Variación genética altitudinal en el crecimiento de plantas de Pinus pseudostrobus Lindl: en campo. Agrociencia 39(5): 575-587.

Weinstein, A. (1989): Provenance evaluation of Pinus halepensis, P. brutia and P. eldarica in Israel. Forest Ecology and Management 26(3): 215-225.

Wright, J. A., L. F. Osorio and W. S. DvoraK (1995): Recent developments in a tree improvement program with Pinus patula in Colombia. Forest Ecology and Management 72(2-3): 229-234.

\title{
Spatial genetic structure in the very rare and species-rich Picea chihuahuana tree community (Mexico)
}

\author{
By C. Z. QuiÑones-PÉRez ${ }^{1)}$, S. L. Simental-Rodríguez ${ }^{1)}$, \\ C. SÁenz-Romero ${ }^{2)}$, J. P. JARAmillo-Correa ${ }^{3)}$ and C. Wehenkel ${ }^{1), *}$
}

(Received 24 ${ }^{\text {th }}$ March 2014)

\begin{abstract}
In natural plant populations, the spatial genetic structure (SGS) is occasionally associated with evolutionary and ecological features such as the mating system, individual fitness, inbreeding depression and natural selection of the species of interest. The very rare Mexican $P$. chihuahuana tree community covers an area no more than 300 ha and has been the subject of several studies concerning its ecology and population genetics. The

1) Instituto de Silvicultura e Industria de la Madera, Universidad Juárez del Estado de Durango, Ciudad Universitaria, Boulevard del Guadiana \#501, C.P. 34120, Durango, Dgo. México.

$\left.{ }^{2}\right)$ Instituto de Investigaciones Agropecuarias y Forestales, Universidad Michoacana de San Nicolás de Hidalgo $\mathrm{Km} 9.5$ carr. Morelia-Zinapécuaro, Tarímbaro Michoacán 58880, Mexico. Currently at: INRA, UMR 1202 BIOGECO, F-33610 Cestas, France \& Univ. Bordeaux, UMR 1202 BIOGECO, F-33615 Pessac, France.

3) Instituto de Ecología, Universidad Nacional Autónoma de Mexico, Ciudad Universitaria, Circuito Exterior s/n. Apartado Postal 70-275, 04510 Mexico, D.F.

*) Corresponding author: C. WeHENkEL. Ciudad Universitaria, Boulevard del Guadiana \#501, C.P. 34120, Durango, Dgo. México. Phone: +52(618) 827-12-15, Fax: (618) 825-18-86. E-Mail: wehenkel@ujed.mx.
\end{abstract}

overall aim of most of these studies has been to obtain data to help design preservation and conservation strategies. However, analysis of the fine-scale SGS in this special forest tree community has not yet been conducted, which might help enrich the above mentioned conservation programs. In this study, we examined the SGS of this community, mostly formed by $P$. chihuahuana Martínez, Pinus strobiformis Ehrenberg ex Schlechtendah, Pseudotsuga menziesii (Mirb.) Franco, and Populus tremuloides Michx, in 14 localities at both the fine and large scales, with the aim of obtaining a better understanding of evolutionary processes. We observed a non-significant autocorrelation in fine-scale SGS, suggesting that the genetic variants of all four tree species are randomly distributed in space within each sampled plot of $50 \times 50 \mathrm{~m}$. At the larger scale, the autocorrelation was highly significant for $P$. chihuahuana and $P$. menziesii, probably as a result of insufficient gene flow due to the extreme population isolation and small sizes. For these two species our results provided strong support for the theory of isolation by distance.

Key words: Community genetics, AFLP, gene flow, selection, Sierra Madre Occidental, Pinus strobiformis Ehrenberg ex Schlechtendah, Pseudotsuga menziesii (Mirb.) Franco, Populus tremuloides Michx. 


\section{Introduction}

The geographical distribution of genetic variation, i.e., spatial genetic structure (SGS), is an important theoretical and experimental component of population genetics (EPPERSON, 1993). A decrease in the strength of the genetic relationship between pairs of individuals is expected with increasing distance (WRIGHT, 1943). In natural plant populations, the SGS is occasionally associated with evolutionary and ecological genetics and can be influenced by different processes, like mating system, individual fitness, inbreeding depression and natural selection (EPPERSON, 1993; DEGEN et al., 2001; EPPERSON and Gi Chung, 2001). Specifically, the SGS is determined by how gene flow through pollen and seed dispersal change as geographical distance increases. Because seed dispersal influences many key aspects of plant biology, including colonization of new sites, metapopulation dynamics and diversity in plant communities (CAIN et al., 2000), analysis of SGS can be helpful for the conservation and management of natural populations (MCCUE et al., 1996).

Analysis of spatial genetic structure has been the subject of numerous research studies since the 1940s and remains a relevant issue today (WRIGHT, 1943; TrOUPIN et al., 2006; VAlBUENA-CARABAÑA et al., 2007; DE LAFONTAINE et al., 2013). Empirical studies have assessed fine-scale SGS within plant populations by using genetic markers and spatial autocorrelation techniques. These studies have generally provided qualitative descriptions of SGS (VEKEMANS and HARDY, 2004). Spatial genetic analysis complements methods that examine processes occurring at larger geographical scales, such as the landscape scale (CLARK et al., 1999; SÁEnZ-Romero et al., 2001; SÁENZ-Romero and GURIES, 2002; Mock et al., 2007) or larger scale migration and colonization events (DEGEN et al., 2001). However, detection of SGS is strongly dependent on both the choice of molecular markers and the strategy used to sample the population under study (JUMP and PEÑUELAS, 2007).

Several studies of forest tree species have investigated spatial genetic structure by the use of allozyme markers (e.g., in eastern white pine) (EPPERSON and Gi CHUNG, 2001) and microsatellites (e.g., in common ash, white pine, and oak) (HEUERTZ et al., 2003; MARQUARDT and EPPERSON, 2004; VALBUENA-CARABAÑA et al., 2007). JUMP and PEÑUELAS (2007) conducted spatial genetic analyses of pairwise kinship coefficients with similar loci (SSRs) joined by amplified fragment length polymorphisms (AFLP). They found that the SGS estimated with the last type of markers could be detected at distances nearly four times larger than previously estimated with other molecular markers, thus indicating a persistent effect of restricted gene flow at small spatial scales and a higher reliability of AFLPs for estimating SGS. The usefulness of AFLP-markers to analyze large scale genetic structures was further demonstrated by LEINEMANN et al. $(2013,2014)$ for two shrub species (Coryllus avellana and Prunus spinosa) with different gene flow systems.

Picea chihuahuana Martínez is an endemic conifer species in Mexico and is considered endangered, according to the official Mexican ruling (NoRMA OFICIAL MEXICANA, 2010). To date, 40 populations comprising a mini- mum total of 42,600 individuals (LEDIG et al., 2000) have been identified in three separate groups in the Sierra Madre Occidental, at altitudes of between 2,100 and 3,000 $\mathrm{m}$ a.s.l. These populations are located in humid valleys and form clusters within gallery forests and often include other tree species of the genera Pinus, Quercus, Abies, Pseudotsuga, Populus, Juniperus, Prunus, and Cupressus (GoRDON, 1968; NARVÁEZ, 1984; LEDIG et al., 2000; QUIÑONES-PÉREZ et al., 2014).

This very rare pine-spruce-cedar community (hereafter referred to as the $P$. chihuahuana tree community) spans on area of no more than 300 ha that is mostly well preserved and remains largely untouched by humans, because of its isolation at high altitudes in very rugged mountains (LEDIG et al., 1997; LEDIG et al., 2000). The $P$. chihuahuana tree community has been the subject of several studies concerning its ecology and population genetics. The overall aim of most of these studies has been to obtain data to help design preservation and conservation strategies (NARVÁEZ, 1984; LEDIG et al., 1997; LEDIG et al., 2000; JARAMILLO-CORREA et al., 2006; WeHENkEL et al., 2012; WeHENKEL and SÁENZ-Romero, 2012; QuiÑONES-PÉREZ et al., 2012; QUIÑONES-PÉREZ et al., 2014; WeHENKEL et al., 2014; MendozA-MAYA et al., 2015). However, analysis of the fine-scale SGS in this special forest tree community has not yet been conducted, which might help enrich the abovementioned conservation programs.

In this study, we examined the SGS of this community, mostly formed by $P$. chihuahuana Martínez, Pinus strobiformis Ehrenberg ex Schlechtendah, Pseudotsuga menziesii (Mirb.) Franco, and Populus tremuloides Michx, in 14 localities at both the fine (in 0.25 ha plots) and large (minimum $60 \mathrm{~km}$ distance class) scales, with the aim of obtaining a better understanding of the complex interaction between the local dispersal, the mating system of the species (particularly $P$. chihuahuana) and other evolutionary processes. Because of the isolated location and strongly mixed nature of this tree community, which often results in low population densities of the each single tree species, we expected a significant autocorrelation at different spatial scales due to restricted gene flow and increasing drift (HAMPE and PETIT, 2005; Dick et al., 2008).

\section{Materials and Methods}

\section{Study area}

In order to determine the SGS of the $P$. chihuahuana tree community, 14 populations located in the State of Durango and Chihuahua, Northwestern Mexico, were analyzed. The populations studied are listed in Table 1 and their locations are shown in Fig. 1. Each population was represented by one plot of $50 \times 50 \mathrm{~m}(0.25 \mathrm{ha})$ placed at the population center (Fig. 2). The target tree species $P$. chihuahuana, $P$. strobiformis, $P$. menziesii, and $P$. tremuloides and all other tree taxa species with diameter at breast height $(\mathrm{DBH}) \geq 7 \mathrm{~cm}$ were fully scored; the $\mathrm{DBH}$, height and $\mathrm{x}, \mathrm{y}$ coordinates were also recorded. The total number of tree species within each of the populations in the $P$. chihuahuana tree community is shown in Table 2. 


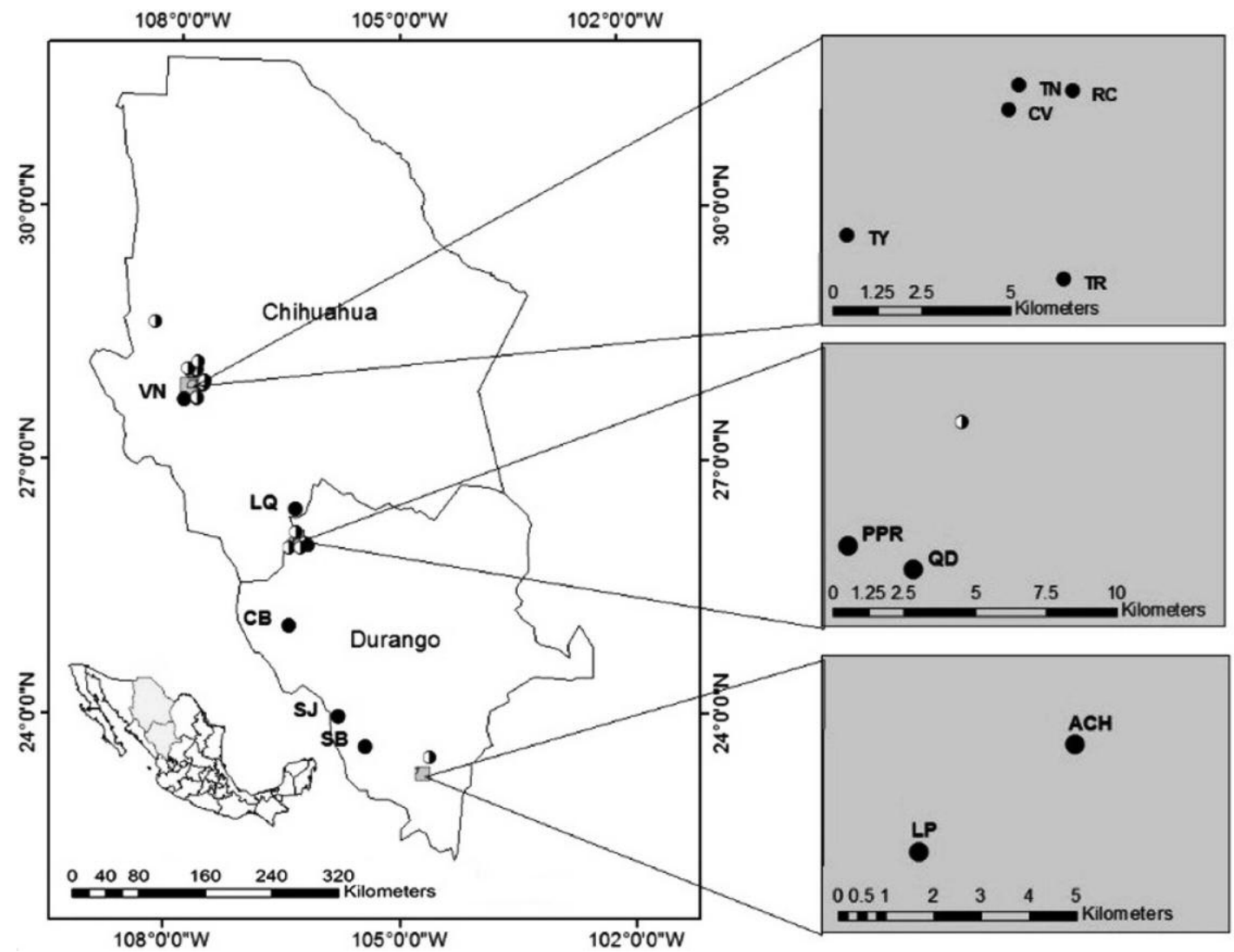

Figure 1. - Map of the 40 known Picea chihuahuana tree communities and the locations of the 14 populations surveyed herein (black circles) in the State of Durango and Chihuahua, Northwest Mexico. Population codes as in Table 1.

\section{Plant material and AFLP analyses}

In order to estimate the SGS, DNA data was obtained by the amplified fragment length polymorphism (AFLP) technique. Needles were sampled from 669 individuals of $P$. chihuahuana (of which 475 were seedlings and saplings $<7 \mathrm{~cm} D B H$ from natural regeneration), 129 Pinus strobiformis (of which 85 were obtained from natural regeneration), 63 Pseudotsuga menziesii (of which 46 were gathered from natural regeneration), and 76 Populus tremuloides (of which 58 were natural regeneration) in all 14 locations (Fig. 1).

AFLP fingerprints were generated according to a modified version of the protocol described by VOS et al. (1995). The DNA was extracted with the QIAGEN DNeasy96 plant kit and digested with the restriction enzymes EcoRI and MseI. PCR amplification was carried out with double-stranded EcoRI and MseI adaptors ligated to the end of the restriction fragments to produce template DNA. In pre-AFLP amplification, the PCR products were treated with the primer combination E01/M03 and in the selective AFLP amplification with E35 and M70 for Picea chihuahuana, E35 and with M63+C for Pseudotsuga menziesii, Pinus strobiformis, and Populus tremuloides, in a Peltier Thermal Cycler (PTC-200 version 4.0, MJ Research).

Finally, a data matrix was constructed from the presence (coded by 1 ) or absence ( 0 ) at potential band positions. Each band detected (presence) corresponds to a dominant genetic variant (plus phenotype) with an unknown mode of inheritance of this potential band position (detected fragment length) (KRAUSS, 2000;

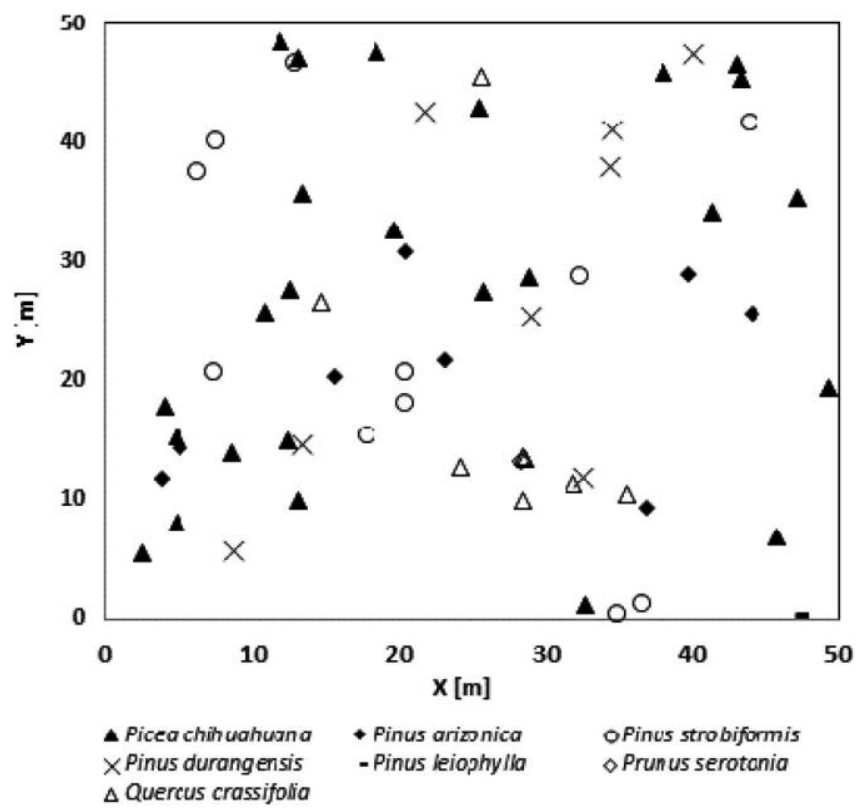

Figure 2. $-50 \times 50 \mathrm{~m}$ plot illustrating the location of each tree with diameter at breasts height (DBH) above $7 \mathrm{~cm}$ in the very rare and species-rich Picea chihuahuana tree community in El Venado location $(V N)$, Chihuahua, Mexico. 
BonIN et al., 2004). Absence of a band reflects the recessive genetic variant (minus phenotype) at the given position (locus).

\section{Spatial Structural Analysis of AFLP data}

Spatial genetic structure at both the local and broad scales was analyzed using the Spatial Genetic Software (DEGEN et al., 2001). The spatial distance between two data points was calculated as the Euclidean ground distance (DEGEN et al., 2001). Within the 50 × $50 \mathrm{~m}$ plots (at fine scale), and provided that there were sufficient trees $\geq 7 \mathrm{~cm} \mathrm{DBH}$ in each spatial distance-class, all SGS statistics were computed for the 5 and $10 \mathrm{~m}$ distanceclass distributions, as well as for distributions with minimum 30 tree pairs per distance-class. However, the distance-class distributions did not always comply with Degen's (2000) recommendation of a minimum of 30 tree pairs for each distance class for a more robust permutation test. At the end, ten plots with $P$. chihuahuana, one plot with $P$. menziesii, one plot with $P$. strobiformis, and one plot with $P$. tremuloides were analyzed at this fine scale.

At the large scale (minimum $60 \mathrm{~km}$ distance-class distribution), SGS analysis was conducted for a minimum of 100 pairs of trees for each distance class. Because of the lack of sufficient trees $\geq 7 \mathrm{~cm} \mathrm{DBH}$ of Pinus strobiformis, Pseudotsuga menziesii, and Populus tremuloides in some of the $50 \times 50 \mathrm{~m}$ plots (Table 2), AFLP data from regeneration of these species, but with unknown $\mathrm{x}$ and $\mathrm{y}$ coordinates within the plots, were added to complete the analysis of large-scale SGS.

The different AFLP data matrices were used to compute the genetic dissimilarity $\left[D_{i j}\right]$ between the binary vectors of two individuals, $i$ and $j$, using Tanimoto distance (DEICHSEL and TRAMPISCH, 1985):

$$
0 \leq D_{i j}=1-\frac{v_{i j}}{v_{i j}+y_{i}+y_{j}} \leq 1
$$

where $v_{i j}$ represents the number of shared fragments between individuals $i$ and $j$, and $y_{i}$ and $y_{j}$ denote the fragments that only exist in one individual ( $i$ or $j$, respectively). Genetic distograms were then constructed to infer spatial patterns. The overall mean of genetic distances between all individuals of each species served as a reference for random spatial structure (DEGEN, 2000).

The presence of statistically significant deviation from a spatial random distribution was tested by randomization permutation methods (MANLY, 1997). The aggregation index $(C E)$ of CLARK and EvANS (1954) was calculated as an indicator of spatial structures of the studied tree positions: values of $[C E]<1$ indicate a clumped and aggregated structures, $[C E]=1$ indicates a random distribution and $[C E]>1$ indicates a regular dis tribution. The $95 \%$ confidence interval $(C I)$ was used. $P(D)<(-C I)$ equals the probability that the observed value is lower than the lower limit of the confidence interval; $P(D)>(+C I)$ equals the probability that the observed value is greater than the upper limit of the confidence interval.

Then, the binary AFLP data matrix was used to perform Principal Coordinate Analysis (PCoA) on GenAlex 6 (PeAkall and Smouse, 2012) by using the Nei Genetic Distance (NEI, 1972, 1978) for calculating similarities. The first two coordinates were used to represent genetic variation among populations for all four tree species.

Table 1. - 14 Locations of the Picea chihuahuana tree community studied: 1) La Tinaja (TN), 2) El Ranchito $(R C), 3)$ El Cuervo $(C V), 4)$ Talayote $(T Y), 5)$ Las Trojas $(T R), 6)$ El Venado $(V N)$, 7) La Quebrada $(L Q), 8)$ Paraje Piedra Rayada $(P P R), 9)$ Quebrada de los Durán (Arroyo del Indio Ignacio) $(Q D), 10)$ Cebollitas $(C B), 11)$ San José de las Causas $(S J), 12)$ Santa Bárbara (Arroyo del Infierno) $(S B), 13)$ Arroyo del Chino $(A C H)$, and 14) La Pista (Arroyo de La Pista) $(L P)$.

\begin{tabular}{|c|c|c|c|c|c|c|}
\hline Code & Location & Property & Municipality & $\begin{array}{l}\text { Latitude } \\
\mathbf{N}\end{array}$ & $\begin{array}{l}\text { Longitude } \\
\text { W }\end{array}$ & $\begin{array}{c}\text { Altitude } \\
\mathrm{m}\end{array}$ \\
\hline $\mathrm{TN}$ & La Tinaja & Ejido El Ranchito & Bocoyna & $27^{\circ} 57^{\prime} 27^{\prime \prime}$ & $107^{\circ} 46^{\prime} 13^{\prime \prime}$ & 2,380 \\
\hline $\mathrm{RC}$ & El Ranchito & Ejido El Ranchito & Bocoyna & $27^{\circ} 57^{\prime} 20^{\prime \prime}$ & $107^{\circ} 45^{\prime} 12^{\prime \prime}$ & 2,414 \\
\hline CV & El Cuervo & Ejido El Ranchito & Bocoyna & $27^{\circ} 57^{\prime} 01^{\prime \prime}$ & $107^{\circ} 46^{\prime} 18^{\prime \prime}$ & 2,500 \\
\hline TY & Talayote & Ejido Los Volcanes & Bocoyna & $27^{\circ} 55^{\prime} 03^{\prime \prime}$ & $107^{\circ} 49^{\prime} 01^{\prime \prime}$ & 2,355 \\
\hline TR & Las Trojas & Ejido El Ranchito & Bocoyna & $27^{\circ} 54^{\prime} 27^{\prime \prime}$ & $107^{\circ} 45^{\prime} 17^{\prime \prime}$ & 2,395 \\
\hline $\mathrm{VN}$ & El Venado & Ejido San Javier & Bocoyna & $27^{\circ} 45^{\prime} 41^{\prime \prime}$ & $107^{\circ} 41^{\prime} 33^{\prime \prime}$ & 2,311 \\
\hline LQ & La Quebrada & $\begin{array}{l}\text { Ejido El Caldillo y su anexo } \\
\text { El Vergel }\end{array}$ & Balleza & $26^{\circ} 28^{\prime} 13^{\prime \prime}$ & $106^{\circ} 21^{\prime} 51^{\prime \prime}$ & 2,730 \\
\hline PPR & $\begin{array}{l}\text { Paraje Piedra } \\
\text { Rayada }\end{array}$ & Ejido Chiqueros & Guanaceví & $26^{\circ} 09^{\prime} 15^{\prime \prime}$ & $106^{\circ} 24^{\prime} 17^{\prime \prime}$ & 2,600 \\
\hline QD & $\begin{array}{l}\text { Quebrada de los } \\
\text { Durán }\end{array}$ & Ejido Chiqueros & Guanaceví & $26^{\circ} 08^{\prime} 48^{\prime \prime}$ & $106^{\circ} 22^{\prime} 53^{\prime \prime}$ & 2,570 \\
\hline $\mathrm{CB}$ & Cebollitas & Private property & Canelas & $25^{\circ} 05^{\prime} 55^{\prime \prime}$ & $106^{\circ} 26^{\prime} 27^{\prime \prime}$ & 2,450 \\
\hline SJ & $\begin{array}{l}\text { San José de las } \\
\text { Causas }\end{array}$ & Ejido San José de las Causas & San Dimas & $24^{\circ} 01^{\prime} 07^{\prime \prime}$ & $105^{\circ} 47^{\prime} 56^{\prime \prime}$ & 2,480 \\
\hline SB & Santa Bárbara & Ejido El Brillante & $\begin{array}{l}\text { Pueblo } \\
\text { Nuevo }\end{array}$ & $23^{\circ} 39^{\prime} 44^{\prime \prime}$ & $105^{\circ} 26^{\prime} 20^{\prime \prime}$ & 2,725 \\
\hline $\mathrm{ACH}$ & Arroyo del Chino & $\begin{array}{l}\text { Santa María Magdalena de } \\
\text { Taxicaringa }\end{array}$ & Mezquital & $23^{\circ} 21^{\prime} 05^{\prime \prime}$ & $104^{\circ} 43^{\prime} 05^{\prime \prime}$ & 2,600 \\
\hline LP & La Pista & $\begin{array}{l}\text { Santa María Magdalena de } \\
\text { Taxicaringa }\end{array}$ & Mezquital & $23^{\circ} 19^{\prime} 52^{\prime \prime}$ & $104^{\circ} 45^{\prime} 00^{\prime \prime}$ & 2,685 \\
\hline
\end{tabular}


Because SGS could be also influenced by selection (EPPERSON, 1992), the proportion of candidate AFLP loci under natural selection were calculated using BayeScan v2.1 software (FolL and GAGGIOTTI, 2008), which is based on the multinomial Dirichlet model and uses a Reversible Jump Markov Chain Monte Carlo (RJMCMC) algorithm to obtain posterior distributions. If the results showed a positive value of the locus-specific com-

Table 2. - Number of trees per species in plots of 0.25 ha for each one of 14 locations of Picea chihuahuana tree community studied herein.

\begin{tabular}{|c|c|c|c|c|c|c|c|c|c|c|c|c|c|c|c|}
\hline Species & TN & RC & $\mathrm{CV}$ & TY & TR & VN & LQ & PPR & QD & CB & SJ & SB & ACH & LP & Total \\
\hline $\begin{array}{l}\text { Abies durangensis } \\
\text { Martínez } \\
\text { Cupressus lindleyi }\end{array}$ & - & - & - & - & - & - & - & - & - & 18 & 9 & 14 & - & - & 41 \\
\hline $\begin{array}{l}\text { Klotzsch ex } \\
\text { Endl. }\end{array}$ & - & - & - & - & - & - & - & - & - & 10 & 24 & 99 & 10 & 4 & 47 \\
\hline $\begin{array}{l}\text { Juniperus deppeana } \\
\text { Steud. }\end{array}$ & - & - & - & - & - & - & - & - & 1 & - & - & 3 & - & 1 & 5 \\
\hline $\begin{array}{l}\text { Picea chibuabuana } \\
\text { Martínez }\end{array}$ & 33 & 11 & 22 & 28 & 12 & 27 & 33 & 23 & 23 & 11 & 12 & 6 & 5 & 24 & 270 \\
\hline $\begin{array}{l}\text { Pinus arizonica } \\
\text { Engelm. } \\
\text { Pinus strobiformis }\end{array}$ & 2 & 27 & 8 & 5 & 4 & 8 & 5 & 6 & 89 & - & - & - & - & - & 154 \\
\hline $\begin{array}{l}\text { Ehrenberg ex } \\
\text { Schlechtendah }\end{array}$ & 33 & 30 & 32 & 4 & 23 & 11 & 40 & - & - & 34 & 4 & - & 4 & - & 215 \\
\hline $\begin{array}{l}\text { Pinus cooperi } \\
\text { Martínez }\end{array}$ & - & - & - & - & - & - & - & - & - & - & 30 & 4 & - & 61 & 95 \\
\hline $\begin{array}{l}\text { Pinus durangensis } \\
\text { Martínez }\end{array}$ & 4 & - & 19 & 1 & 5 & 8 & - & - & - & 4 & - & 1 & - & - & 42 \\
\hline $\begin{array}{l}\text { Pinus leiophylla } \\
\text { Schl. \& Cham. } \\
\text { Pinus teocote }\end{array}$ & - & - & - & - & - & 1 & - & - & - & - & 1 & - & - & - & 2 \\
\hline $\begin{array}{l}\text { Schiede ex } \\
\text { Schltdl. \& } \\
\text { Cham. } \\
\text { Populus }\end{array}$ & - & - & - & - & - & - & - & - & - & - & - & 2 & - & - & 2 \\
\hline $\begin{array}{l}\text { tremuloides } \\
\text { Michx. }\end{array}$ & - & 12 & - & - & 33 & - & 16 & 1 & 11 & - & - & - & - & - & 73 \\
\hline $\begin{array}{l}\text { Prunus serotina } \\
\text { Ehrh. } \\
\text { Pseudotsuga }\end{array}$ & 2 & 3 & 1 & 4 & 1 & 1 & - & - & - & - & - & - & - & - & 12 \\
\hline $\begin{array}{l}\text { menziesii (Mirb.) } \\
\text { Franco }\end{array}$ & - & - & - & 15 & - & - & - & 8 & 9 & 10 & - & 35 & 11 & - & 88 \\
\hline Quercus spp. & 2 & 4 & - & 1 & 11 & 9 & 14 & - & - & - & 10 & 20 & - & 1 & 72 \\
\hline Total & 76 & 87 & 82 & 58 & 89 & 65 & 108 & 38 & 133 & 87 & 90 & 184 & 30 & 91 & 1218 \\
\hline
\end{tabular}

Table 3. - Analysis of fine-scale spatial genetic structure in P. chihuahuana tree community by using a distance class of size 5 meters, 5,000 permutations and a $95 \%$ confidence interval.

\begin{tabular}{cccccccc}
\hline Loc & SP & $\mathbf{N}$ & $\begin{array}{c}\text { MD } \\
(\mathbf{m})\end{array}$ & $\mathbf{C A}$ & $\mathbf{P}(\mathbf{D})<(-\mathbf{C I})$ & $\mathbf{P}(\mathbf{D})>(+\mathbf{C I})$ & $\mathbf{M T}$ \\
\hline TY & Pch & 23 & 5.84 & 0.58 & $\mathrm{~ns}$ & $\mathrm{~ns}$ & $8 /(0-5)$ \\
TN & Pch & 31 & 3.40 & 0.55 & $\mathrm{~ns}$ & $\mathrm{~ns}$ & $24 /(10-15)$ \\
CV & Pch & 16 & 4.56 & 0.53 & $\mathrm{~ns}$ & $\mathrm{~ns}$ & $4 /(40-45,45-50)$ \\
VN & Pch & 23 & 3.44 & 0.50 & $\mathrm{~ns}$ & $\mathrm{~ns}$ & $4 /(30-35)$ \\
TR & Pch & 12 & 7.46 & 0.49 & $\mathrm{~ns}$ & $\mathrm{~ns}$ & $3 /(20-25)$ \\
RC & Pch & 40 & 3.61 & 0.49 & $\mathrm{~ns}$ & $\mathrm{~ns}$ & $25 /(45-50)$ \\
\hline LQ & Pch & 25 & 5.83 & 0.48 & $\mathrm{~ns}$ & $\mathrm{~ns}$ & $10 /(0-5)$ \\
QD & Pch & 20 & 5.13 & 0.47 & $\mathrm{~ns}$ & $\mathrm{~ns}$ & $5 /(45-50)$ \\
PPR & Pch & 20 & 5.45 & 0.42 & $\mathrm{~ns}$ & $\mathrm{~ns}$ & $8 /(45-50)$ \\
\hline LP & Pch & 17 & 6.30 & 0.27 & $0.998^{* *} /(15-20)$ & $\mathrm{ns}$ & $6 /(0-5,15-20,45-50)$ \\
\hline TN & Pst & 10 & 7.71 & 0.60 & $\mathrm{~ns}$ & $\mathrm{~ns}$ & $1 /(30-35)$ \\
\hline
\end{tabular}

Note: $L o c=$ location of the $P$. chihuahuana tree population; $S P=$ species; $N=$ tree number $M D=$ mean distance to the next tree; $C A=$ calculated average; $M T=$ minimum tree pairs per class (distance class); $P(\mathrm{D})<(-\mathrm{CI}), P(\mathrm{D})>(+\mathrm{CI})=$ autocorrelation $P$ value; $P c h=$ Picea chihuahuana Pst $=$ Pinus strobiformis; asterisks indicate significance: $(* *)$ at $1 \% / 99 \%$ and (***) at $0.1 \% / 99.9 \%$; $\mathrm{ns}=$ not significant 
Table 4. - Analysis of fine-scale spatial genetic structure in $P$. chihuahuana tree community by using a distance class of size 10 meters, 5,000 permutations and a $95 \%$ confidence interval.

\begin{tabular}{cccccccc}
\hline Loc & SP & $\mathbf{N}$ & $\begin{array}{c}\text { MD } \\
(\mathbf{m})\end{array}$ & CA & $\mathbf{P}(\mathbf{D})<(-\mathbf{C I})$ & $\mathbf{P}(\mathbf{D})>(+\mathrm{CI})$ & MT \\
\hline TY & Pch & 23 & 5.84 & 0.58 & $\mathrm{~ns}$ & $\mathrm{~ns}$ & $28 /(0-10)$ \\
TN & Pch & 31 & 3.40 & 0.55 & $\mathrm{~ns}$ & $\mathrm{~ns}$ & $59 /(10-20)$ \\
CV & Pch & 16 & 4.56 & 0.53 & $\mathrm{~ns}$ & $\mathrm{~ns}$ & $8 /(40-50)$ \\
VN & Pch & 23 & 3.44 & 0.50 & $\mathrm{~ns}$ & $\mathrm{~ns}$ & $14 /(30-40)$ \\
TR & Pch & 12 & 6.43 & 0.49 & $\mathrm{~ns}$ & $\mathrm{~ns}$ & $6 /(20-30)$ \\
RC & Pch & 40 & 3.61 & 0.49 & $\mathrm{~ns}$ & $\mathrm{~ns}$ & $85 /(40-50)$ \\
\hline LQ & Pch & 25 & 5.83 & 0.48 & $\mathrm{~ns}$ & $\mathrm{~ns}$ & $24 /(0-10)$ \\
QD & Pch & 20 & 5.13 & 0.47 & $\mathrm{~ns}$ & $\mathrm{~ns}$ & $13 /(40-50)$ \\
PPR & Pch & 20 & 5.45 & 0.42 & $\mathrm{~ns}$ & $0.997 * * /(0-10)$ & $20 /(0-10)$ \\
\hline LP & Pch & 17 & 6.30 & 0.27 & $\mathrm{~ns}$ & $\mathrm{~ns}$ & $14 /(40-50)$ \\
\hline TN & Pst & 10 & 7.71 & 0.60 & $\mathrm{~ns}$ & $\mathrm{~ns}$ & $3 /(30-40)$ \\
\hline
\end{tabular}

Note: $L o c=$ location of the $P$. chihuahuana tree population; $S P$ = species; $N=$ tree number; $M D=$ mean distance to the next tree; $C A=$ calculated average; $M T=$ minimum tree pairs per class (distance class); $P(\mathrm{D})<(-\mathrm{CI}), P(\mathrm{D})>(+\mathrm{CI})=$ autocorrelation $P$ value; $P c h=$ Picea chihuahuana $;$ Pst $=$ Pinus strobi formis; asterisks indicate significance: $(* *)$ at $1 \% / 99 \%$ and $(* * *)$ at $0.1 \% / 99.9 \% ; \mathrm{ns}=$ not significant.

ponent $(\alpha)$ and a posterior probability $>0.95$, we expected diversifying selection, whereas negative $\alpha$ values with posterior probabilities $>0.95$ indicated possible balancing or purifying selection (http://cmpg.unibe.ch/ software/bayescan/files/BayeScan2.1_manual.pdf; FOLL and GagGiotTi, 2008; Foll et al., 2010).

The parameters of the chain and of the model were as follows: output number of iterations $(5,000)$, thinning interval size (10), pilot runs (20), length of pilot runs $(5,000)$, additional burn in $(50,000)$, prior odds for the neutral model (10), lower boundary for uniform prior on the inbreeding coefficients $F_{i s}(0)$ and the higher boundary for uniform prior on $F_{i s}(1)$.

\section{Results}

The AFLP primer combination resulted in 243 polymorphic bands of 75-450 base pairs across all individuals of Picea chihuahuana, while the respective numbers of bands for Pinus strobiformis, Pseudotsuga menziesii, and Populus tremuloides were 250, 207 and 237. At the fine scale $(5 \mathrm{~m}, 10 \mathrm{~m}$ and maximal $28 \mathrm{~m}$ distance-class distributions) and for the 10 plots analyzed, autocorrelations were not significant ( $P \geq 0.01$ or $P \leq 0.99$ ), except for the $3^{\text {th }}$ distance class in the $L P$ plot (Table 3 ) and for the $1^{\text {st }}$ distance class in PPR (Tables 4 and 5). The mean genetic distance between $P$. chihuahuana trees in LP (the southern most population) was the lowest in this study. The CE index was not significant, except in the population $T N$ (Table 5), indicating a generally spatial random distribution of tree positions.

At the large scale, the SGS analysis included a set of 14 locations of the tree community under study. This analysis revealed highly significant autocorrelations $(P \geq 0.99)$ for all four tree species (Table 6). However, only Picea and Pseudotsuga followed a clear trend and a significant decline in the strength of the genetic relationship with increasing distance between pairs of individuals (Fig. $3 a, 3 b, 3 c$, and $3 d$ ). In this case, the $\mathrm{CE}$ was also highly significant, indicating a clumped and aggregated spatial distribution of tree positions.

Principal Coordinate Analysis revealed an informative separation of populations. The first three coordinates explained $86.4 \%$ of the $P$. chihuahuana, $82.5 \%$ of the P. strobiformis, $88.0 \%$ of the P. tremuloides, and $94.1 \%$ of the P. menziesii of AFLP variation. By plotting the first two coordinates (which together explained $78.2 \%$ of the Picea AFLP variation, $71.1 \%$ of the Pinus AFLP variation, $79.9 \%$ of the Populus AFLP variation and $86.2 \%$ of the Pseudotsuga AFLP variation) the northern populations of these four trees species almost always clustered separately from those of the central and southern regions (Fig. 4).

Table 5. - Analysis of fine-scale spatial genetic structure in P. chihuahuana tree community by using a minimum the 30 pairs of data points for Picea chihuahuana and maximum possible number of tree pairs for Pinus strobiformis, Populus tremuloides and Pseudotsuga menziesii, 5,000 permutations and a 95\% confidence interval.

\begin{tabular}{ccccccccc}
\hline Loc & SP & N & MD $(\mathbf{m})$ & CE & CA & $\mathbf{P}(\mathbf{D})<(-\mathbf{C I})$ & $\mathbf{P}(\mathbf{D})>(+\mathbf{C I})$ & $\mathbf{M T}$ \\
\hline TY & Pch & 23 & 5.84 & $1.22 \mathrm{~ns}$ & 0.58 & $\mathrm{~ns}$ & $\mathrm{~ns}$ & $33 /(42-63)$ \\
TN & Pch & 31 & 3.40 & $0.62 * * *$ & 0.55 & $\mathrm{~ns}$ & $\mathrm{~ns}$ & $45 /(64-80)$ \\
CV & Pch & 16 & 4.56 & $0.68 \mathrm{~ns}$ & 0.53 & $\mathrm{~ns}$ & $\mathrm{~ns}$ & $29 /(27-54)$ \\
VN & Pch & 23 & 4.74 & $0.94 \mathrm{~ns}$ & 0.50 & $\mathrm{~ns}$ & $\mathrm{~ns}$ & $30 /(0-11)$ \\
TR & Pch & 12 & 6.43 & $0.99 \mathrm{~ns}$ & 0.49 & $\mathrm{~ns}$ & $\mathrm{~ns}$ & $34 /(0-28,28-56)$ \\
RC & Pch & 40 & 3.61 & $0.91 \mathrm{~ns}$ & 0.49 & $\mathrm{~ns}$ & $\mathrm{~ns}$ & $50 /(45-60)$ \\
\hline QD & Pch & 20 & 5.13 & $1.14 \mathrm{~ns}$ & 0.47 & $\mathrm{~ns}$ & $\mathrm{~ns}$ & $33 /(0-11,33-44)$ \\
LQ & Pch & 25 & 4.59 & $1.03 \mathrm{~ns}$ & 0.47 & $\mathrm{~ns}$ & $\mathrm{~ns}$ & $40 /(11-22)$ \\
PPR & Pch & 20 & 5.45 & $1.19 \mathrm{~ns}$ & 0.42 & $\mathrm{~ns}$ & $0.998^{* *}(0-14)$ & $36 /(0-14)$ \\
\hline LP & Pch & 17 & 6.30 & $1.28 \mathrm{~ns}$ & 0.27 & $\mathrm{~ns}$ & $\mathrm{~ns}$ & $30 /(0-14)$ \\
\hline TN & Pst & 10 & 7.71 & $1.24 \mathrm{~ns}$ & 0.60 & $\mathrm{~ns}$ & $\mathrm{~ns}$ & $9 /(28-56)$ \\
\hline TR & Pop & 9 & 2.10 & $0.82 \mathrm{~ns}$ & 0.53 & $\mathrm{~ns}$ & $\mathrm{~ns}$ & $14 /(25-50)$ \\
\hline QD & Pme & 7 & 3.17 & $1.19 \mathrm{~ns}$ & 0.48 & $\mathrm{~ns}$ & $\mathrm{~ns}$ & $7 /(10-20)$ \\
\hline
\end{tabular}

Note: $L o c=$ location of the $P$. chihuahuana tree population; $S P=$ species; $N=$ tree number; $M D=$ mean distance to the next tree; $C E=$ aggregation index; $C A=$ calculated average; $M T=$ minimum tree pairs per class (distance class); $P(\mathrm{D})<(-\mathrm{CI}), P(\mathrm{D})\rangle(+\mathrm{CI})=$ autocorrelation $P$ value; $P$ ch $=$ Picea chihuahuana $;$ Pst $=$ Pinus strobiformis $;$ Pop $=$ Populus tremuloides; Pme = Pseudotsuga menziesii; asterisks indicate significance: (**) at $1 \% / 99 \%$ and $(* * *)$ at $0.1 \% / 99.9 \%$; ns = not significant. 
Table 6. - Analysis of large-scale spatial genetic structure in P. chihuahuana tree community, by using 5,000 permutations and a $95 \%$ confidence interval.

\begin{tabular}{|c|c|c|c|c|c|c|c|}
\hline SP & $\mathbf{N}$ & MD (km) & CE & CA & $\mathbf{P}(\mathrm{D})<(-\mathrm{CI})$ & $\mathrm{P}(\mathrm{D})>(+\mathrm{CI})$ & MT \\
\hline Pch & 669 & 1.00 & $0.000 * * *$ & 0.55 & $0.9999 * * * /(0-60)$ & $\begin{array}{c}0.9999 * * * /(60-120) \\
0.9999 * * * /(240-300) \\
0.9999 * * * /(360-420)\end{array}$ & $5,000 /(360-420)$ \\
\hline Pst & 130 & 1.39 & $0.000 * * *$ & 0.66 & $0.996 * * /(90-180)$ & ns & $400 /(90-180)$ \\
\hline Pop & 76 & 1.41 & $0.000 * * *$ & 0.63 & $\begin{array}{c}0.9999 * * * /(0-150) \\
0.9999 * * * /(300-450)\end{array}$ & $0.9999 * * * /(150-300)$ & $280 /(300-450)$ \\
\hline Pme & 63 & 1.41 & $0.000 * * *$ & 0.60 & $\begin{array}{c}0.9999 * * * /(0-150) \\
0.9999 * * * /(300-450)\end{array}$ & $\begin{array}{l}0.9999 * * * /(150-300) \\
0.9999 * * * /(450-600)\end{array}$ & $250 /(450-600)$ \\
\hline
\end{tabular}

Note: $S P=$ species; $N=$ tree number; $M D=$ mean distance to the next tree; $C E=$ aggregation index; $C A=$ calculated average $M T=$ minimum tree pairs per class (distance class); $P(\mathrm{D})<(-\mathrm{CI})$, $P(\mathrm{D})>(+\mathrm{CI})=$ autocorrelation $P$ value Pch $=$ Picea chihuahuana Pst $=$ Pinus strobiformis $;$ Pop $=$ Populus tremuloides; Pme = Pseudotsuga menziesii; asterisks indicate significance: $(* *)$ at $1 \% / 99 \%$ and $(* * *)$ at $0.1 \% / 99.9 \% ; \mathrm{ns}=$ not significant. The distance class size is given in $\mathrm{km}$.

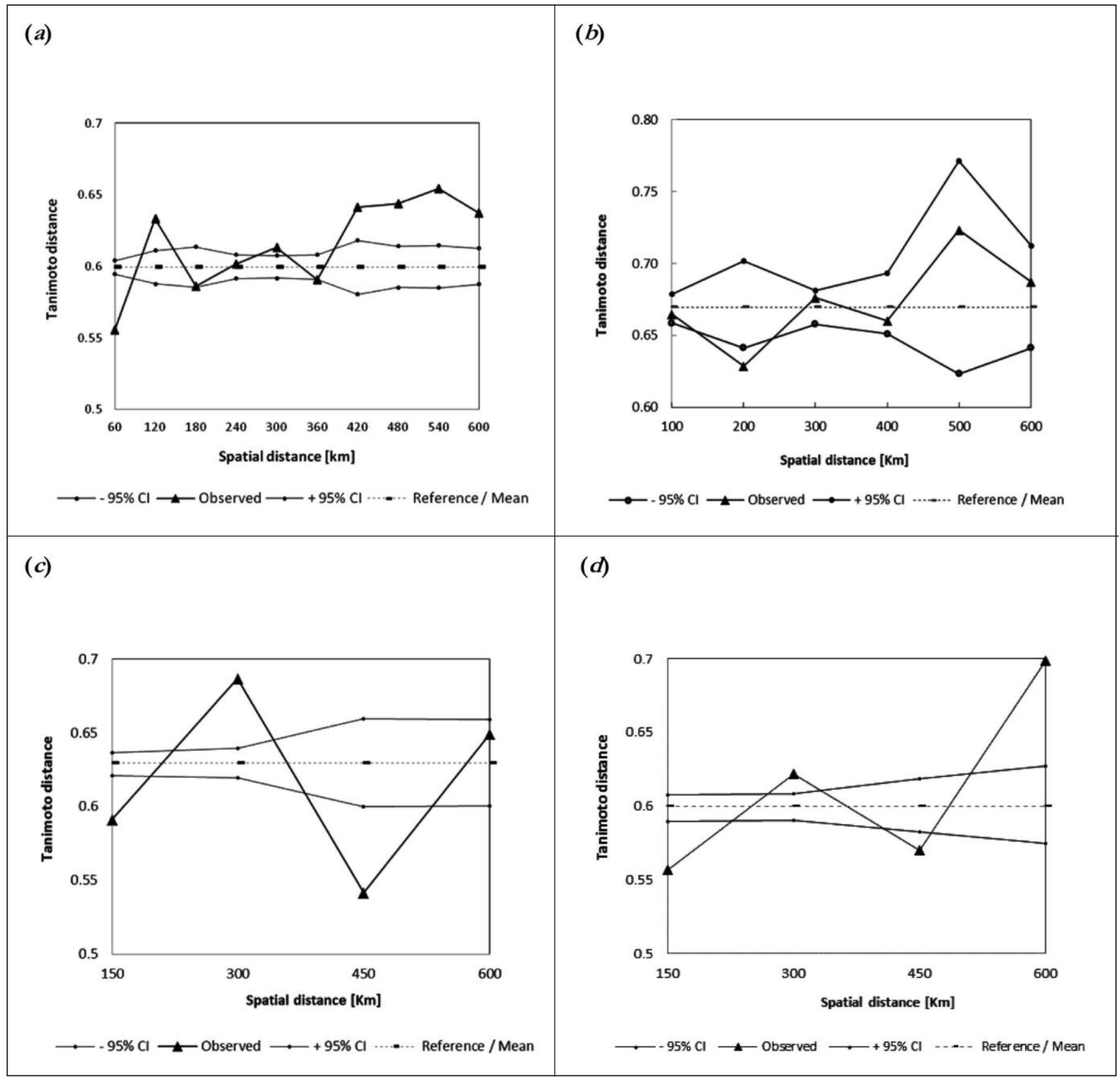

Figure 3. - Large-scale spatial genetic structure analysis, based on AFLP data. Distogram calculated using mean Tanimoto distance for Picea chihuahuana (a), Pinus strobiformis (b), Populus tremuloides (c), and Pseudotsuga menziesii (d), with a minimum of 100 tree pairs per distance class. $\mathrm{CI}=$ confidence interval. 


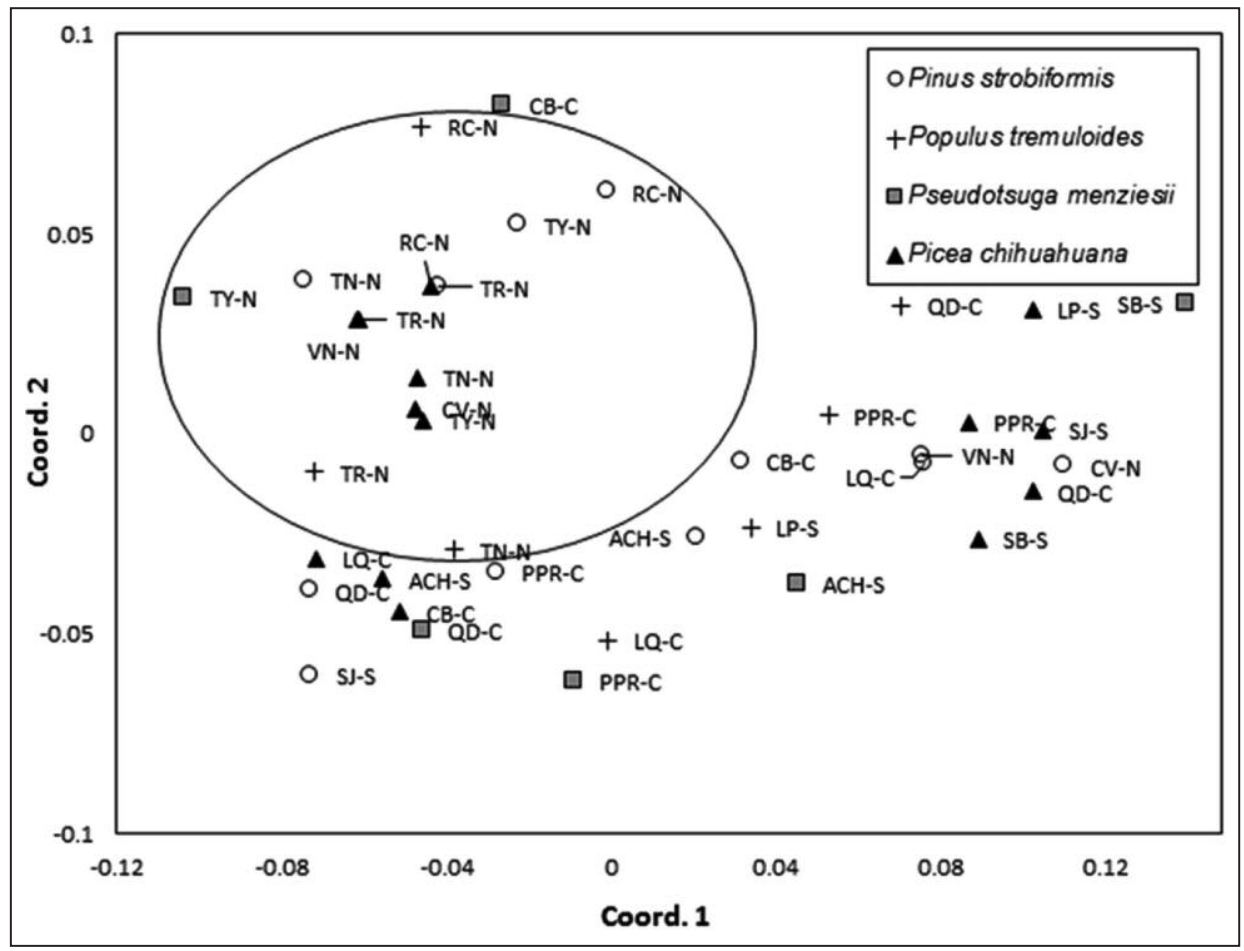

Figure 4. - Separation of Picea chihuahuana, Pinus strobiformis, Populus tremuloides, and Pseudotsuga menziesii populations by the first two coordinates in Principal Coordinates analysis. The populations codes are: $T N=$ La Tinaja, $R C=E l$ Ranchito, $C V=$ El Cuervo, $T Y=$ Talayote, $T R=$ Las Trojas, $V N=$ El Venado, $L Q=$ La Quebrada, $P P R=$ Paraje Piedra Rayada, $Q D=$ Quebrada de los Durán (Arroyo del Indio Ignacio), $C B=$ Cebollitas, $S J=$ San José de las Causas, $S B=$ Santa Bárbara (Arroyo del Infierno), $A C H=$ Arroyo del Chino, and $L P=$ La Pista (Arroyo de La Pista). $\mathrm{N}=$ northern, $\mathrm{C}=$ central, and $\mathrm{S}=$ southern populations.

According to the outlier analysis (BayeScan), diversifying selection should be significantly influencing $6.3 \%$ of the AFLP loci in P. chihuahuana, $1.4 \%$ in $P$. strobiformis, $6.5 \%$ in P. tremuloides, and $0.5 \%$ in P. menziesii. However, balancing or purifying selection should be affecting $8.3 \%$ of the AFLP loci in $P$. chihuahuana, and no AFLP loci in the other three species.

\section{Discussion and Conclusions}

SGS within plant populations has been investigated at both fine (FRELICH et al., 2003; TROUPIN et al., 2006; VALBUENA-CARABAÑA et al., 2007; KetTle et al., 2011) and large scales (FRECKLETON and WATKINSON, 2002) often using spatial autocorrelation methods. In the tree populations under study here, most of the times we observed a non-significant autocorrelation for fine-scale SGS (Tables 3, 4 and 5), suggesting that the genetic variants of $P$. chihuahuana, $P$. strobiformis, $P$. menziesii, and $P$. tremuloides are randomly distributed in space within each sampled plot. Such a pattern can be explained by sufficient gene flow (both by pollen and seed) within each particular stand. Furthermore, the low population density of each tree species imposed by mixed stand structure did not form a significant family-related structure in the plots and, therefore, did not support an isolation-by-distance process at the fine scale (in $50 \times 50 \mathrm{~m}$ plots), as observed for other wind dispersed tree species in Europe and North America (GEHRING and DelPH, 1999; MARQUARDT and EPPERSON, 2004; VEKEMANS and HARDY, 2004; Troupon et al., 2006). Moreover, in the study plots used here in (of only $0.25 \mathrm{ha}$ ), the impact of uniformly-acting selection countering significant autocorrelation would probably be weak, although microenvironmental selection cannot be excluded (EPPERSON, 1992; QUIÑONES-PÉREZ et al., 2014). In this study, AFLP loci affected by possible balancing or purifying selection were only detected in $P$. chihuahuana. Moreover, their proportion was low with $8.3 \%$. Previous studies in Picea abies, Picea glauca and Pinus monticola have reported low proportions of putative adaptive AFLP loci (2-12\%) (ACHERÉ et al., 2005; NAMROUd et al., 2008; RICHARDSON et al., 2009), thus suggesting that the observed patterns are likely produced by stochastic forces. Such patterns can actually be explained by the strong inbreeding depression at early seedling stages as observed for most tree taxa (PETIT and HAMPE, 2006).

At the larger scale, the autocorrelation was highly significant for P. chihuahuana and P. menziesii (Table 6), probably as a result of limited gene flow due to the extreme population isolation and small sizes of (Fig. 3 and 4, Table 1). Such features should prompt genetic drift resulting in high genetic divergence (HAMPE and Petit, 2005), as previously shown for P. chihuahuana with both allozymes and chloroplast markers (LEDIG et 
al., 1997; JARAMILlO-CoRREA et al., 2006). For P. chihuahuana and $P$. menziesii at the large scale, our results provided strong support for the theory of isolation by distance that predicts the expected pattern of SGS at drift-dispersal equilibrium (VEKEMANS and HARDY, 2004). The SGS analyze of $P$. strobiformis showed a very weak spatial distance - genetic distance relationship (Fig. 3 and 4), probably caused by a strong seed interchange, likely prompted by birds, such as the Mexican Jay (Aphelocoma wollweberi), and due to the continuous and broad geographic distribution of this tree species (LOONEY and WARING, 2013). However, we did not find an explanation for why $P$. tremuloides individuals in the distance class of 300 to $450 \mathrm{~km}$ were genetically more similar than more closely located individuals (Fig. 3). Further research might be needed to clarify such unexpected finding.

Differential selection could play a role generating the SGS found in response to environmental clines, because of the important hitchhiking effects expected at a high selfing rate in small and isolated tree populations/communities (VEKEMANS and HARDY, 2004). However, the low proportion of putatively adaptive AFLPs found in the four analyzed tree species (0.5 to 6.5\%) suggests that the impact of differential selection is not important.

In view of the vital relevance of gene flow in generating, maintaining and conserving genetic diversity, understanding spatial genetic structure would be valuable in reproductive, morphological and demographic studies carried out with the aim of designing strategies for the conservation and sustainable management of the very small, isolated and rare $P$. chihuahuana tree community (WEHENKEL and SÁENZ-ROMERO, 2012; WeHENKEL et al., 2014). For example, other studies have been suggested to decrease the accumulated inbreeding in small Picea chihuahuana populations by introducing new genotypes (seedlings originated from seeds collected from different populations than the targeted population) (LEDIG, 2012; MENDOZA-MAYA et al., 2015). This raises the question as to whether we should mimic natural spatial structures when planting new genotypes.

The following management actions could be also helpful for the preservation of the isolated and rare $P$. chihuahuana tree community: a) in situ conservation by regulating livestock and controlling forest fires, b) elimination of competing vegetation (other tree species) in the vicinity of priority populations, c) establishment of artificial regeneration using reproductive local material gathered from well-selected sites outside the priority population's boundaries (but not from inside the priority population), d) increasing the size of the smallest populations by planting individuals at the endangered populations edges, and e) ex situ conservation along with assisted migration in response to climate change, and f) long-term seed conservation by seed storage in gene banks (WEHENKEL and SÁENZ-ROMERo, 2012; QUIÑONES-PÉREZ et al., 2014).

\section{Acknowledgements}

This study was supported by joint funding from the Mexican Council of Science and Technology (CONACyT) and the Ministry of Education (SEP; Project CB-2010-01 158054), the Durango State Ministry of Natural Resources and Environment, the Universidad Juárez of the State of Durango, Mexico and ISOGEN, Göttingen, Germany. Cuauhtémoc Sáenz Romero received a sabbatical year fellowship from CONACyT (232838). We also thank Dr. OLEKSANDRA KuCHMA for her excellent technical assistance and comments.

\section{References}

Acheré, V., J. M. Favre, G. Besnard and S. Jeandroz (2005): Genome organization of molecular differentiation in Norway spruce (Picea abies). Mol. Ecol. 14: 3191-3201.

Bonin, A., E. Bellemain, E. P. Bronken, F. Pompanon et al. (2004): How to track and assess genotyping errors in population genetics studies. Mol. Ecol. 13: 3261-3273.

Cain, M. L., B. G. Milligan and A. E. Strand (2000): Long-distance seed dispersal in plant populations. Am. J. Bot. 87: 1217-1227.

Clark, P. J. and F. C. Evans (1954): Distance to nearest neighbour as a measure of spatial relationships in populations. Ecology 35: 445-453.

Clark, D. B., M. W. Palmer and D. A. Clark (1999): Edaphic factors and the landscape-scale distributions of tropical rain forest trees. Ecology 80: 2662-2675.

De Lafontaine, G., A. Ducousso, S. Lefevre, E. MagNANOU and R. J. Petit (2013): Stronger spatial genetic structure in recolonized areas than in refugia in the European beech. Mol. Ecol. 22: 4397-4412.

Degen, B. (2000): SGS: Spatial Genetic Software. Computer program and user's manual. http://kourou. cirad.fr/genetique/software.html.

Degen, B., R. Petit and A. Kremer (2001): SGS - Spatial Genetic Software: A Computer Program for Analysis of Spatial Genetic and Phenotypic Structures of Individuals and Populations. J. Hered. 92: 447-448.

Deichsel, G. and H. J. TRAMPISCH (1985): Clusteranalyse und Diskriminanzanalyse. Stuttgart: Gustav Fischer Verlag.

Dick, C.W., F. A. Jones, O. J. Hardy and R. J. Petit (2008): Spatial scales of seed and pollen-mediated gene flow in tropical forest trees. Trop. Plant Biol. 1: 20-33.

EPPERSON, B. K. (1992): Spatial structure of genetic variation within populations of forest trees. New Forest. 6: 257-278.

EPPERSON, B. K. (1993): Recent advances in correlation analysis of spatial patterns of genetic variation. Evol. Biol. 27: 95-155.

EPPERSON, B. K. and M. GI CHUNG (2001): Spatial genetic structure of allozyme polymorphisms within populations of Pinus strobus (Pinaceae). Am. J. Bot. 88: 1006-1010.

Foll, M., M. C. Fischer, G. Heckel and L. Excoffier (2010): Estimating population structure from AFLP amplification intensity. Mol. Ecol. 19: 4638-4647.

Foll, M. and O. E. GaGGiotTi (2008): A genome scan method to identify selected loci appropriate for both dominant and codominant markers: A Bayesian perspective. Genetics 180: 977-993.

Freckleton, R. P. and A. R. WAtKinson (2002): Largescale spatial dynamics of plants: metapopulations, regional ensembles and patchy populations. J. Ecol. 90: $419-434$. 
Frelich, L. E., J. L. MAChado and P. B. Reich (2003): Fine-scale environmental variation and structure of understorey plant communities in two old-growth pine forests. J. Ecol. 91: 283-293.

GEHRING, J. L. and L. F. DELPH (1999): Fine-scale genetic structure and clinal variation in Silene acaulis despite high gene flow. Heredity 82: 628-637.

Gordon, A. G. (1968): Ecology of Picea chihuahuana Martínez. Ecology 49: 880-896.

Heuertz, M., X. Vekemans, J. F. Hausman, M. Palada and O. J. HARDY (2003): Estimating seed vs. pollen dispersal from spatial genetic structure in the common ash. Mol. Ecol. 12: 2483-2495.

HAmpe, A. and R. J. Petit (2005): Conserving biodiversity under climate change: the rear edge matters. Ecol. Lett. 8: $461-467$.

Kettle, C. J., P. M. Hollingsworth, D. Burslem et al. (2011): Determinants of fine-scale spatial genetic structure in three co-occurring rain forest canopy trees in Borneo. Perspect. Plant Ecol. Evol. Syst. 13: 45-54.

KraUss, S. L. (2000): Accurate gene diversity estimates from amplified fragment length polymorphism (AFLP) markers. Mol. Ecol. 9: 1241-1245.

Jump, A. S. and J. PeÑUElAS (2007): Extensive spatial genetic structure revealed by AFLP but not SSR molecular markers in the wind-pollinated tree, Fagus sylvatica. Mol. Ecol. 16: 925-936.

Jaramillo-Correa, J. P., J. Beaulieu, F. T. Ledig and J. Bousquet (2006): Decoupled mitochondrial and chloroplast DNA population structure reveals holocene collapse and population isolation in a threatened mexican-endemic conifer. Mol. Ecol. 15: 2787-2800.

Ledig, F. T., V. Jacob-Cervantes, P. D. Hodgskiss and T. EguILUZ-PIEDRA (1997): Recent evolution and divergence among populations of a rare Mexican endemic, Chihuahua spruce, following Holocene climatic warming. Evolution 51: 1815-1827.

Ledig, F. T., M. Mapula-L, B. Bermejo-V, V. Reyes-H, C. Flores-López and M. A. CAPó-Arteaga (2000): Locations of endangered spruce populations in Mexico and the demography of Picea chihuahuana. Madroño 47: 71-88.

LeDig, F. T. (2012): Climate change and conservation. Acta Silvatica et Lignaria Hungarica. 8: 57-74.

Leinemann, L., W. Steiner, B. Hosius, O. Kuchma, W. Arenhövel, B. Fussi, B. HaAse, R. KÄtzel, M. RogGe and R. Finkeldey (2013): Genetic variation of chloroplast and nuclear markers in natural populations of hazelnut (Corylus avellana L.) in Germany. Plant Syst Evol. 299: 36-378.

Leinemann, L., J. Kleinschmit, B. Fussi, B. Hosius, O. Kuchma, W. Arenhövel, P. Lemmen, R. Kätzel, M. RogGe and R. FinkeldeY (2014): Genetic composition and differentiation of sloe (Prunus spinosa L.) populations in Germany with respect to the tracing of reproductive plant material. Plant Syst. Evol. Online first, DOI 10.1007/s00606-014-1027-7.

LOONEY, C. E. and K. M. WARING (2013): Pinus strobiformis (southwestern white pine) stand dynamics, regeneration, and disturbance ecology: A review. For. Ecol. Manag. 287: 90-102.

MANLY, B. F. J. (1997): Randomization bootstrap and Monte Carlo methods in biology - Chapman and Hall, London, p 399.

MARquARDT, P. E. and B. K. Epperson (2004): Spatial and population genetic structure of microsatellites in white pine. Mol. Ecol. 13: 3305-3315.
McCue, K. A., E. S. Buckler and T. P. Holtsford (1996): A hierarchical view of genetic structure in the rare annual plant Clarkia springuillensis. Conserv. Biol. 10: 1425-1434.

Mendoza-Maya, E., J. Espino-Espino, C. Z. QuiñonesPÉrez, C. Flores-López, C. Wehenkel, J. J. VARGasHernández and C. SÁEnZ-Romero (2015): Proposal for conservation of three endangered species of Mexican spruce. Revista Fitotecnia Mexicana: Manuscript submitted.

Mock, K. E., B. J. Bentz, E. M. O’Neill, J. P. Chong, J. ORwin and M. E. Pfrender (2007): Landscape-scale genetic variation in a forest outbreak species, the mountain pine beetle (Dendroctonus ponderosae). Mol. Ecol. 16: $553-568$.

Namroud, M., J. Beaulieu, N. Juge, J. Laroche and J. BousquET (2008): Scanning the genome for gene single nucleotide polymorphisms involved in adaptive population differentiation in white spruce. Mol. Ecol. 17: 3599-3613.

NARVÁEZ, F. R. (1984): Contribución al Conocimiento de la Ecología de Picea chihuahuana. Tesis profesional (Biología), Universidad Autónoma de Nuevo León, Facultad de Ciencias Biológicas. Mexico.

Norma Oficial Mexicana (2010): NOM-059-ECOL-2010. Protección ambiental - Especies nativas de Mexico de flora y fauna silvestres- Categorías de riesgo y especificaciones para su inclusión, exclusión o cambio. Lista de especies en riesgo. Diario Oficial de la Federación (Segunda sección): 1-77.7.

NEI, M. (1972): Genetic distance between populations. Amer. Nat. 106: 283-392.

NEI, M. (1978): Estimation of average heterozygosity and genetic distance from a small number of individuals. Genetics 89: 583-590.

PeAkall, R. and P. E. SMouse (2012): GenAlEx 6.5: genetic analysis in Excel. Population genetic software for teaching and research - an update. Bioinformatics 28: 2537-2539.

QuiÑones-PÉreZ, C. Z., C. SÁENZ-Romero and C. WeHENKEL (2014): Influence of neighbouring tree species on AFLP variants of endangered Picea chihuahuana populations on the Sierra Madre Occidental, Northeastern Mexico. Pol. J. Ecol. 62: 55-65.

QuiÑones-PÉrez, C. Z., R. Silva-Flores and C. WeHEnkel (2012): Ecology of the Mexican Abies durangensis Martínez. Kastamonu University Journal of Forestry Faculty 12(3): 180-184.

QuiÑones-PÉReZ, C. Z., C. SÁEnZ-Romero, and C. WeHenkel (2014): Genetic diversity and conservation of Picea chihuahuana Martínez: a Review. Afr. J. Biotechnol. 13(28): 2786-2795.

Petit, R. J. and A. HAMPe (2006): Some evolutionary consequences of being a tree. Annu. Rev. Ecol. Evol. Syst. 37: 187-214.

RichaRdson, B. A., G. E. REHFELDT and M. S. KIM (2009): Congruent climate-related genecological responses from molecular markers and quantitative traits for western white pine (Pinus monticola). Int. J. Plant. Sci. 170: 1120-1131.

Sáenz-Romero, C., R. P. Guries and A. I. Monk (2001): Landscape genetic structure of Pinus banksiana: allozyme variation. Can. J. Bot. 79(8): 871-878.

SÁenz-Romero, C. and R. P. Guries (2002): Landscape genetic structure of Pinus banksiana: seedling traits. Silvae Genet. 51(1): 26-35. 